\title{
The Influence of Polymorphisms in Tumor Suppressor Genes in Thyroid Carcinomas
}

\author{
Š. Dvořáková ${ }^{1}$, T. Hálková ${ }^{1,2}$, E. Václavíková ${ }^{1,2}$, V. Sýkorová ${ }^{1}$, J. Včelák ${ }^{1}$, P. Vlček ${ }^{3}$, D. Kodetová ${ }^{4}$, J. Betka ${ }^{5}$, B. Bendlová ${ }^{1}$

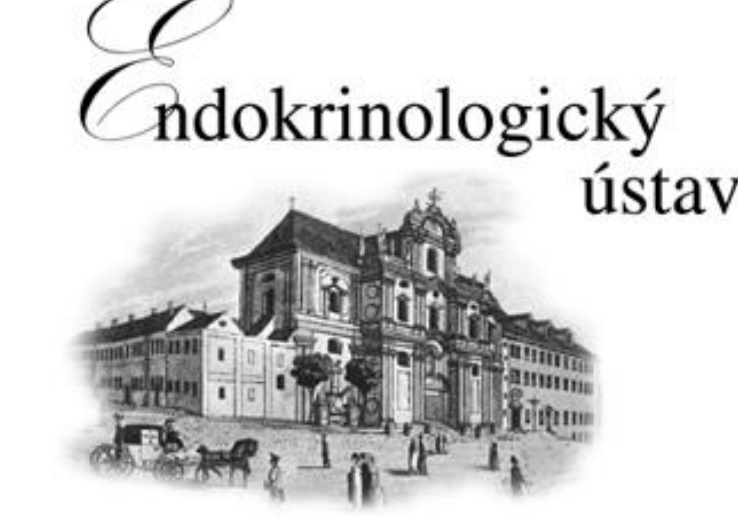
${ }^{1}$ Department of Molecular Endocrinology, Institute of Endocrinology, ${ }^{2}$ Department of Biochemistry, Faculty of Nature Science, ${ }^{3}$ Department of Nuclear Medicine and Endocrinology, ${ }^{4}$ Department of Pathology, ${ }^{5}$ Department of Otorhinolaryngology, Teaching Hospital Motol, \\ Prague, Czech Republic
}

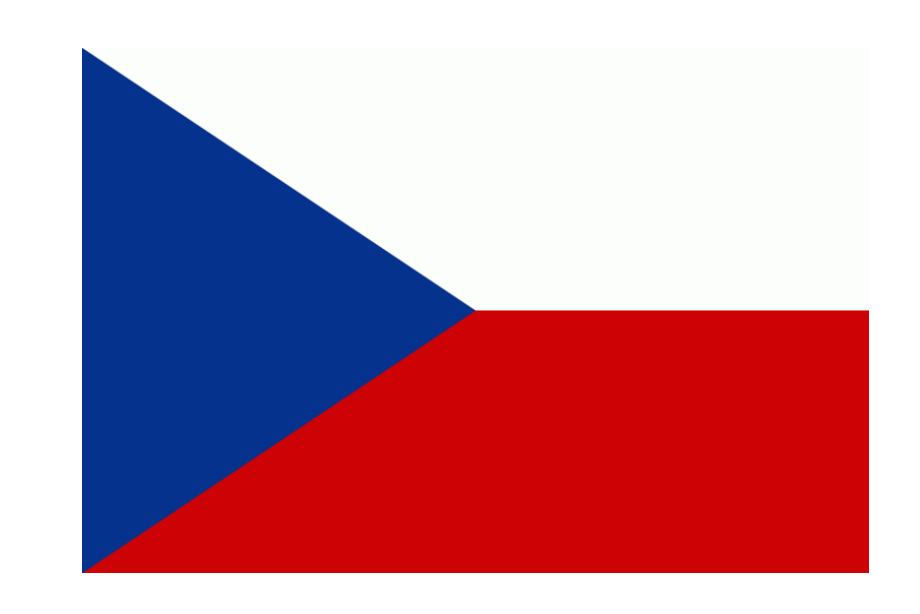

\section{Introduction:}

Thyroid carcinomas are the most often endocrine malignancy and their incidence is still growing. But the genetic predisposition to the development of thyroid cancer is still unknown. Beside mutations in the specific oncogenes, the genetic predisposition to the thyroid cancer could be influenced by risk variants in tumor suppressor genes encoding key proteins in regulation of cell cycle and cell surviving.

\section{CDKN1B (12p13.1-p12)}

- Encoding cyclin-dependent kinase inhibitor 1B (p27, Kip 1)

- Localized in the cell nucleus

- Controls cell proliferation, differentiation and division

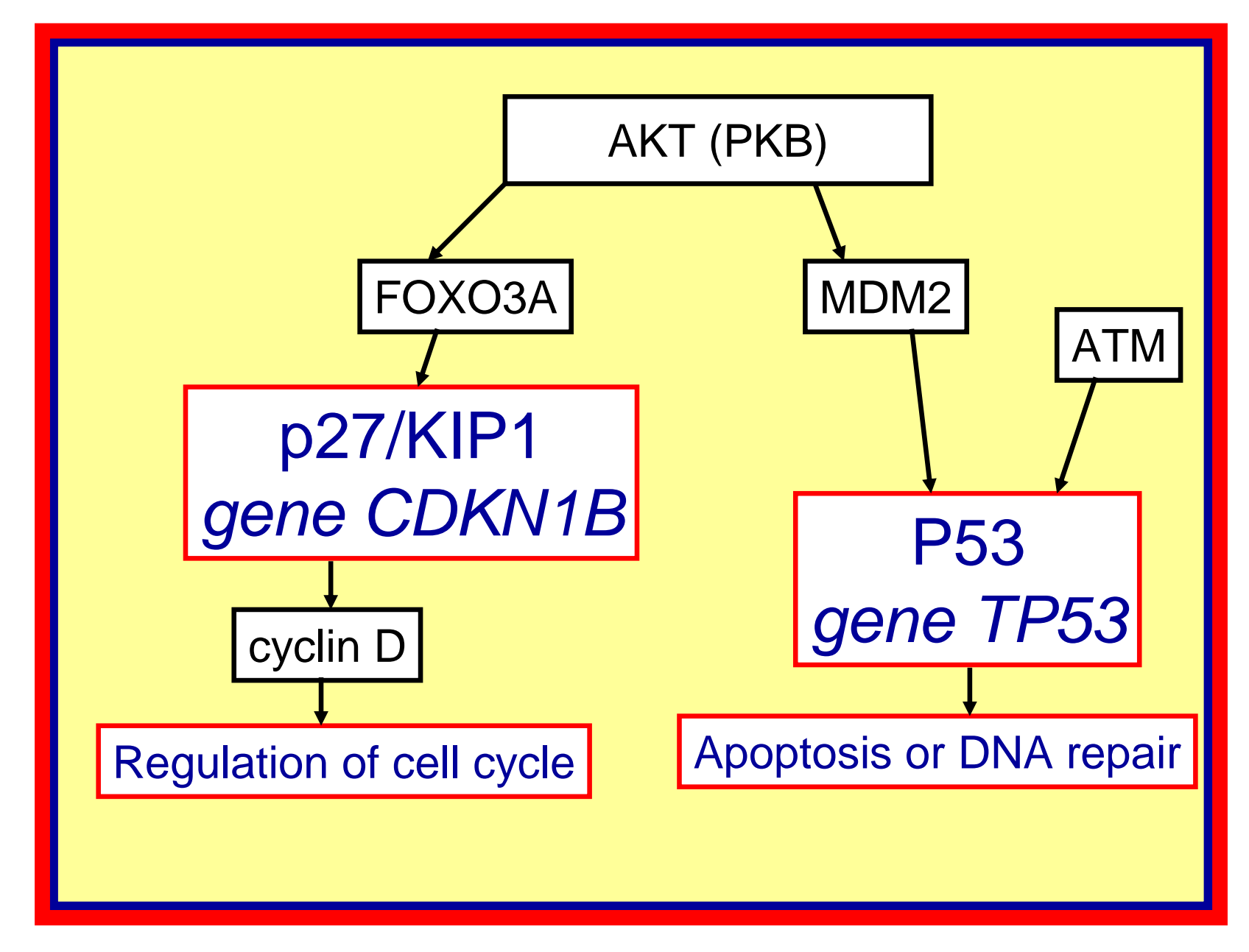

\section{$\underline{\text { TP53 }}$ (17p13.1)}

- Encoding protein p53

- Localized in the cell nucleus

- Regulation of cell division and proliferation

" „The guardian of the genome“

\section{Aim of the study:}

To determine the influence of polymorphisms Val109Gly (T/G) in the gene CDKN1B encoding protein p27/Kip1 and Arg72Pro (C/G) in the gene TP53 encoding protein p53 on the development of the thyroid cancer.

Our cohorts:

- 345 patients with sporadic medullary thyroid carcinoma (MTC)

- 269 patients with papillary thyroid carcinoma (PTC)

- 374 healthy controls

\section{Methods:}

$>$ DNA isolation from peripheral leukocytes or from thyroid cancer tissues - QIAamp DNA Blood Kit or Trizol

$>$ Detection of polymorphisms Val109Gly (T/G) in the gene $C D K N 1 B$ and Arg72Pro (C/G) in the gene TP53 - TaqMan specific assays; Real Time PCR (Light Cycler 480, Roche)

$>$ Statistical evaluation - NCSS 2004 programme (Statistical Solutions, Saugus, MA, USA) and Chi-square test

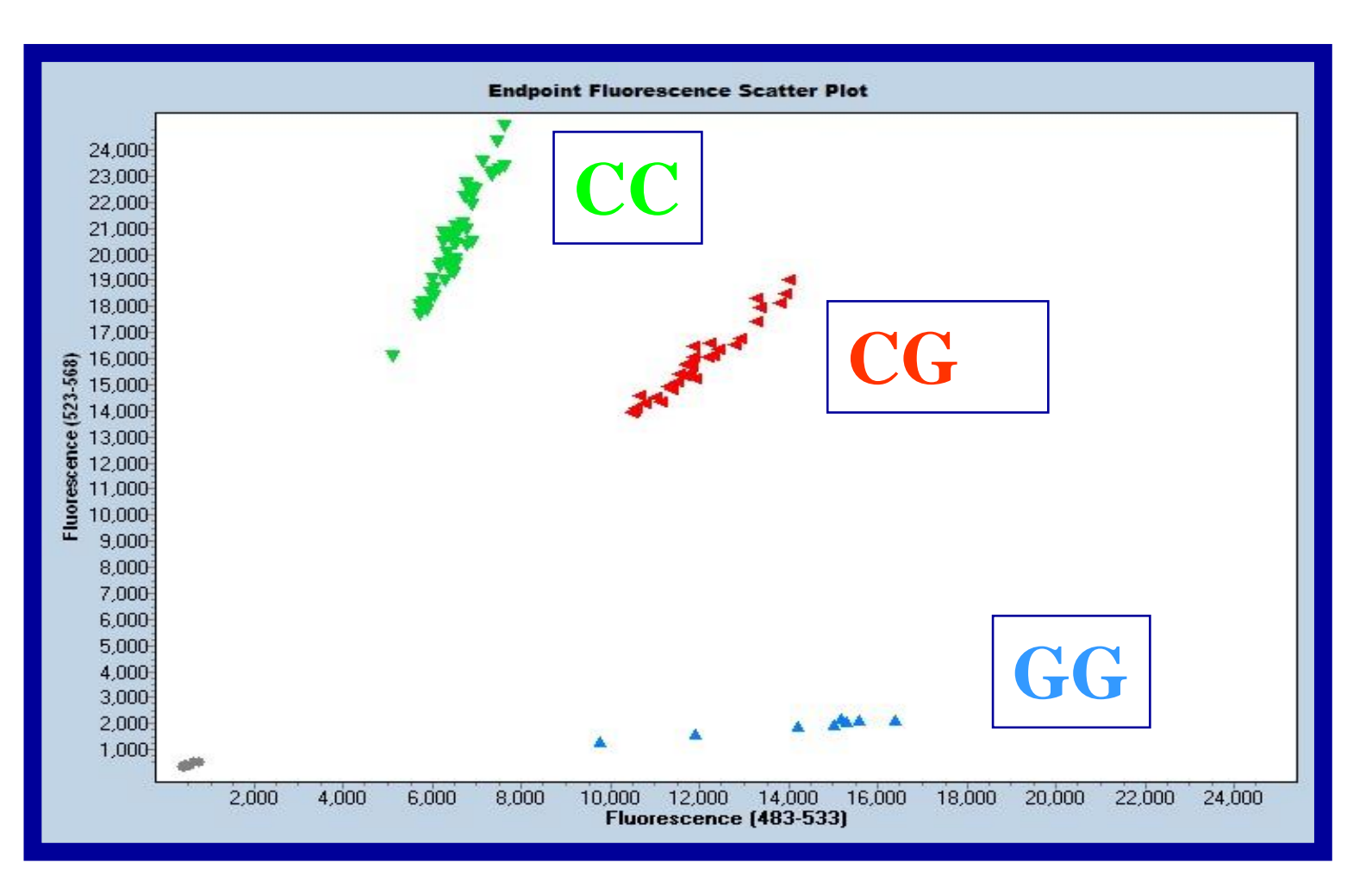

analysis $\operatorname{Arg} 72 \operatorname{Pro}(\mathrm{C} / \mathrm{G})$ in $T P 53$

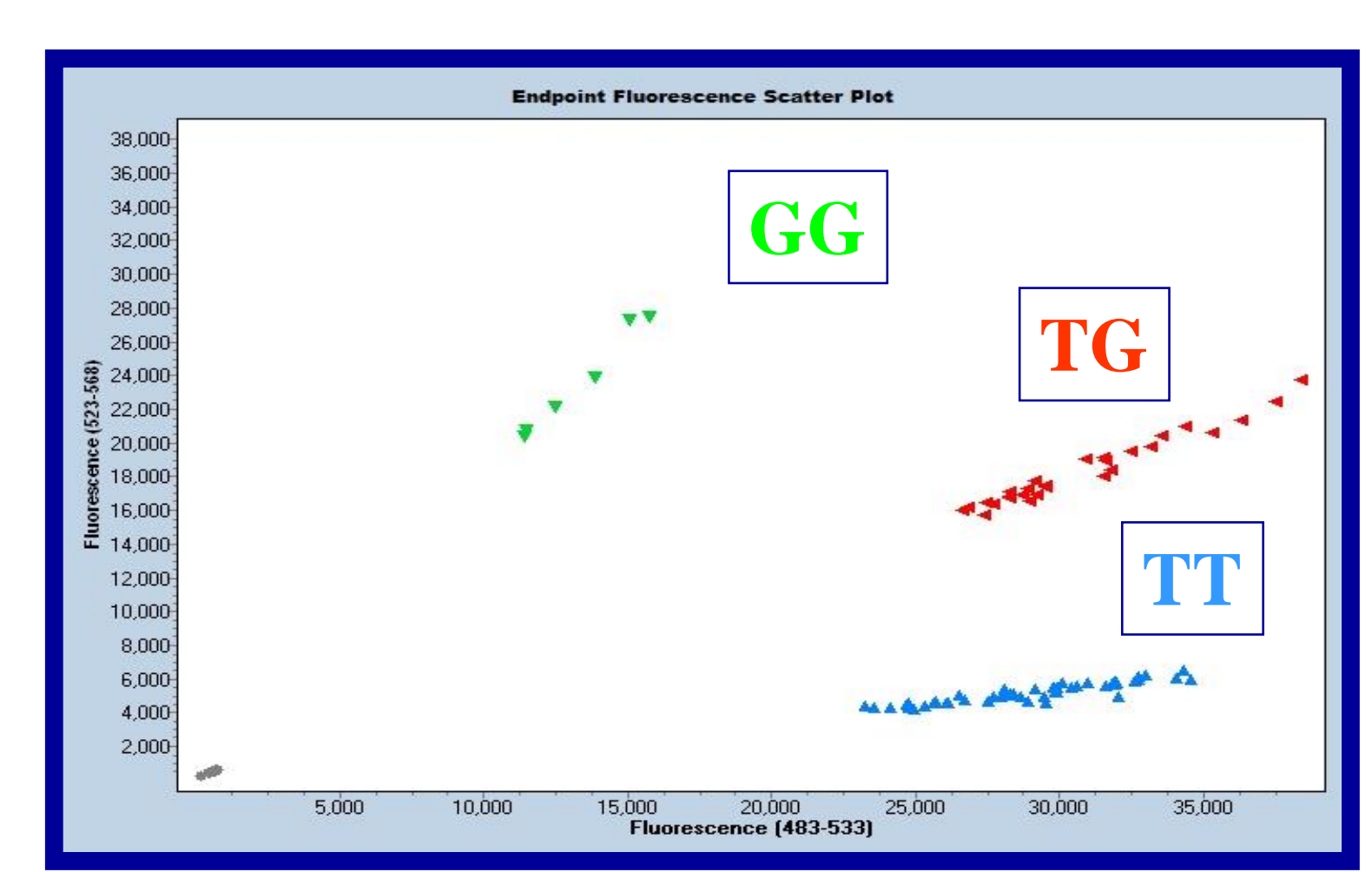

analysis Val109Gly (T/G) in $C D K N 1 B$

\section{Conclusion:}

Although total distributions of alleles of each gene were not statistically different in patients compared to controls, the remarkable risk is in combination of specific alleles of these genes. $G$ allele in TP53 in combination with $\mathrm{T}$ allele in $C D K N 1 B$ is more often in patients with PTC than in controls $(84,4 \%$ vs. $74,7 \%, \mathrm{OR}=1,82$; CI95\% (1,23-2,70); $\mathrm{p}=0,003)$ and specifically the TT genotype in $C D K N 1 B$ is the most risk in comparison with controls $(70,8 \%$ vs. $56,6 \%, \mathrm{OR}=1,86$; CI95\% $(1,18-2,94) ; \mathrm{p}=0,01)$. In MTC patients, C allele in TP53 with GG genotype in CDKN1B is more frequent compared to controls $(6,2 \%$ vs. $2,9 \%$, OR=2,2; CI95\% $(1,19-4,08)$; $\mathrm{p}=0,016)$. It seems that genetic variants of tumor suppressor genes and mainly their cumulative risk effect play a role in the development of PTC and MTC.

This work was supported by IGA MH CZ NT/13901-4 and MH CZ 00023761

\begin{tabular}{|c|c|c|c|c|c|c|c|}
\hline \multirow{2}{*}{ Results: } & TP53 & Controls & $\%$ & MTC & $\%$ & PTC & $\%$ \\
\hline & $\mathrm{CC}$ & 206 & 54,8 & 187 & 54,2 & 145 & 53,7 \\
\hline & CG & 142 & 37,8 & 127 & 36,8 & 106 & 39,3 \\
\hline & GG & 28 & 7,5 & 31 & 9,0 & 19 & 7,1 \\
\hline & $\mathbf{C}$ & 554 & 73,7 & 501 & 72,6 & 396 & 73,3 \\
\hline & G & 198 & 26,3 & 189 & 27,4 & 144 & 26,7 \\
\hline & $C D K N 1 B$ & Controls & $\%$ & MTC & $\%$ & PTC & $\%$ \\
\hline & GG & 15 & 4,0 & 23 & 6,7 & 11 & 4,0 \\
\hline & GT & 138 & 36,9 & 116 & 33,6 & 83 & 30,4 \\
\hline & TT & 221 & 59,1 & 206 & 59,7 & 179 & 65,6 \\
\hline & $\mathbf{G}$ & 168 & 22,5 & 162 & 23,5 & 105 & 19,2 \\
\hline & $\mathbf{T}$ & 580 & 77,5 & 528 & 76,5 & 441 & 80,8 \\
\hline
\end{tabular}

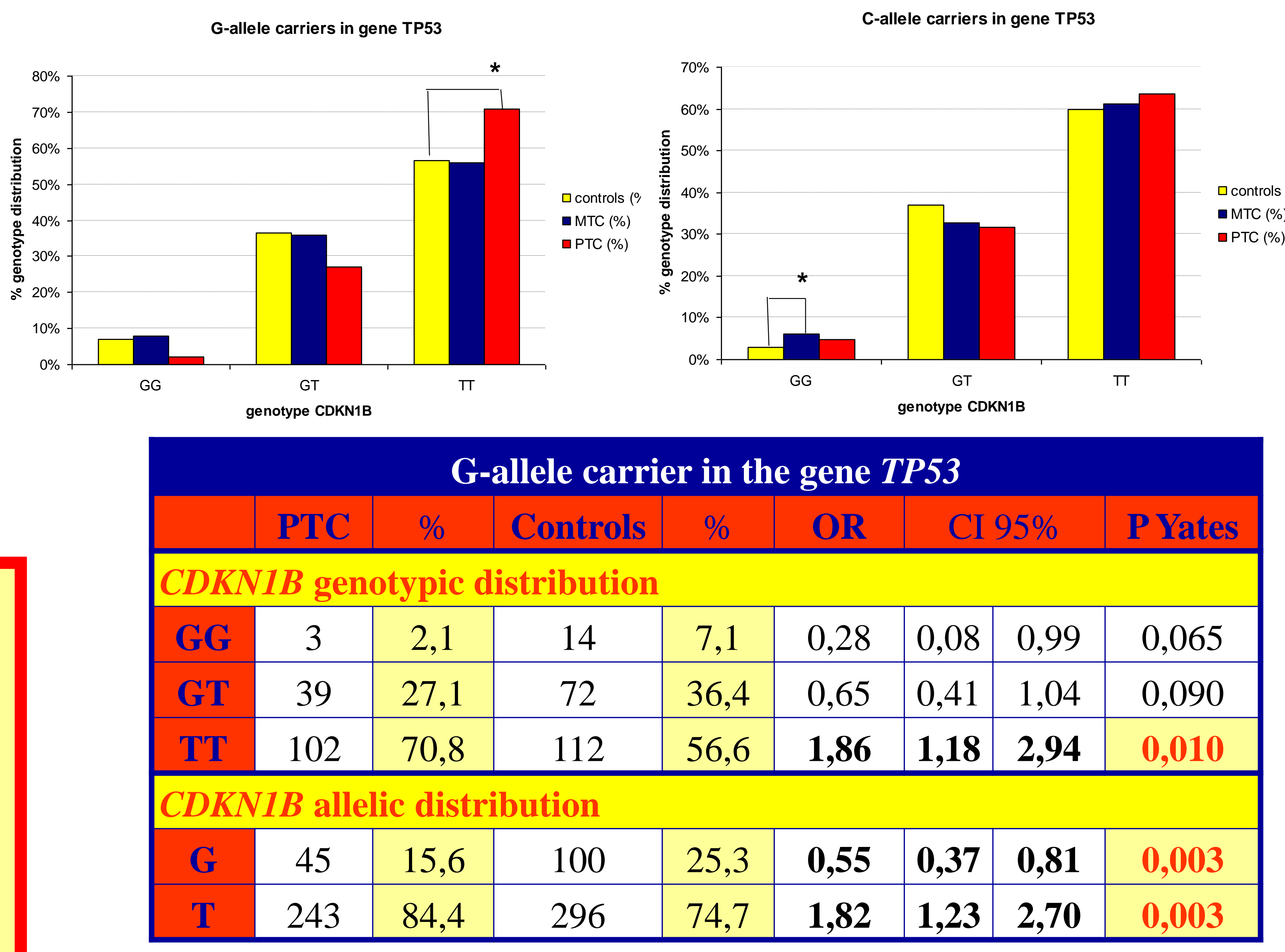

\begin{tabular}{|c|c|c|c|c|c|c|c|c|c|}
\hline \multicolumn{7}{|c|}{ C-allele carriers in the gene TP53 } \\
\hline & MTC & $\%$ & Controls & $\%$ & OR & CI 95\% & P Yates \\
\hline CDKN1B genotypic distribution \\
\hline GG & 31 & 6,2 & 16 & 2,9 & $\mathbf{2 , 2 0}$ & $\mathbf{1 , 1 9}$ & $\mathbf{4 , 0 8}$ & $\mathbf{0 , 0 1 6}$ \\
\hline GT & 164 & 32,7 & 204 & 37,1 & 0,83 & 0,64 & 1,06 & 0,157 \\
\hline TT & 306 & 61,1 & 330 & 60,0 & 1,05 & 0,82 & 1,34 & 0,769 \\
\hline CDKN1B allelic distribution \\
\hline G & 226 & 22,6 & 236 & 21,5 & 1,07 & 0,87 & 1,31 & 0,578 \\
\hline T & 776 & 77,4 & 864 & 78,5 & 0,94 & 0,76 & 1,15 & 0,578 \\
\hline
\end{tabular}

Contact: RNDr. Šárka Dvořáková, PhD, Department of Molecular Endocrinology, Institute of Endocrinology, Narodni 8, Prague 1, 11694,

e-mail: sdvorakova@endo.cz 